\title{
ADMINISTRATIVE AND LEGAL PRINCIPLES OF ACTIVITIES OF TAX AUTHORITIES IN UKRAINE AND EU MEMBER COUNTRIES: COMPARATIVE LEGAL ANALYSIS
}

\author{
Dmytro Andreiev ${ }^{1}$ \\ Educational and Scientific Institute No. 1, \\ National Academy of Internal Affairs, Ukraine \\ Oleg Basai \\ National Academy of Internal Affairs, Ukraine \\ Ruslan Bilokin ${ }^{3}$ \\ Higher Educational Institution of Ukoopspilka \\ "Poltava University of Economics and Trade", Ukraine
}

\begin{abstract}
The aim of the article is a comparative legal analysis of the administrative and legal principles of activities of tax authorities in Ukraine and EU member countries, including the consideration of structural subordination and the place of these authorities in the system of executive power in EU member countries, the scope of authority of their officials; search and characterization of foreign experience, which would be acceptable for implementation and use in national conditions. The subject of the study is the administrative and legal principles of the activities of tax authorities in EU member countries. Methodology. The research is based on a direct comparison of features of the structure and coordination of tax authorities in the European Union and Ukraine. The example of the experience of Germany, France, Sweden, and other countries determines the advantages and disadvantages of different operating conditions of the tax authorities. Based on a comparative legal analysis of the provisions of the current legislation of Ukraine, the possibilities and limits of the application of positive foreign experience in this sphere are determined. The results of the study revealed that the experience of EU countries in providing and organizing the activities of tax authorities in most cases is based on the centralization of the system of tax authorities within a certain executive body, and provision of officials of the latter with a wide range of authorities, and active using of information technology in their activities in taxation and tax control. Practical implications. Interrogation of the foreign administrative and legal principles of the activities of the tax authorities indicates that to increase the operating efficiency of the national system of such departments, it is expedient to extend the limits of their administrative influence, as well as improve the activity by introducing the latest information technologies, following the example of Spain, Austria, etc. However, a comparative legal analysis enabled to determine that the current administrative and legal model of organizing the system of tax authorities is better than in the EU countries, since the existing State Fiscal Service of Ukraine is a completely independent agency, which ensures a higher level of objectivity, rationality, and impartiality of its activities. Relevance/originality. A comparative analysis of the administrative and legal principles of the activities of tax authorities in Ukraine and EU member countries is the framework for developing the most promising sectors of national legislation in this sphere.
\end{abstract}

Key words: administrative and legal principles, EU member countries, foreign experience.

JEL Classification: D73, O52

\footnotetext{
Corresponding author:

${ }^{1}$ Educational and Scientific Institute No. 1, National Academy of Internal Affairs.

E-mail: dmitro@gmail.com

${ }^{2}$ Department of Civil Law and Process, National Academy of Internal Affairs.

E-mail: bov@ukr.net

${ }^{3}$ Department of Law, Higher Educational Institution of Ukoopspilka; "Poltava University of Economics and Trade".

E-mail: ruslan1974@gmail.com
} 


\section{Relevance}

Nowadays, Ukraine is on a new stage of its development due to the entry into the European Union. This aspect calls for the reformation of many spheres of public life in the country through the implementation of European standards in the legislation. In this context, taxation is one of the key objects that need to be improved considering international experience, because the state budget of Ukraine depends directly on the efficiency of its functioning. However, it should be noted that taxation is a quite broad sphere, and the main point in its provision is the activities of tax authorities. All the same, the officials of these agencies are in charge of tax collection monitoring, tax entities accounting, bringing to justice those responsible for tax legislation violations, etc.

In the course of European integration, the issue of forming an effective and efficient system of tax authorities, whose activities would ensure the stability of the tax system and increase revenues to the state budget, arises. However, improvement of these departments is impossible without conducting a comparative legal analysis of the administrative and legal principles of tax authorities in Ukraine and the EU member countries. Since foreign experience will facilitate to synthesize the most perfect model of organization of tax departments on the example of different states.

\section{Literature review}

The theoretical basis of this scientific research was the works of many scientists, who analysed the administrative and legal principles of the activities of various organizations and tax authorities in particular, namely: S.M. Dobrovolska, Ya.V. Melnyk, K.O. Kolchenko, P.M. Talanchuk, I.S. Hrishchenko, O.V. Kuzmenko, D.V. Radko, and others. It is also important to note the scientific and practical value of the research covering some aspects of the organization and operation of tax authorities. V.I. Kravchenko, V.H. Kniaziev, M.P. Kucheriavenko, M.E. Tarasov, D.H. Chernik, and others studied the mentioned issues. However, despite the relevancy of the administrative and legal principles of the activities of tax authorities, no thorough interrogation of the latter from a comparative perspective has been carried out.

The aim of the article is a comparative analysis of administrative and legal principles of tax authorities in Ukraine and in the countries of the European Union.

\section{The main material}

Consideration and comparison of the administrative and legal principles of the organization of national and foreign systems of tax authorities require defining the concept of "administrative and legal principles". The basis of the etymological content of this phrase is the term "principle", which according to the explanatory dictionaries of Ukrainian language, is interpreted as:
1) the basis of something; a fundamental source or basis of something;

2) initial, main position, norm;

3) the basis of the outlook, the rule of conduct;

4) the way, method of doing something (Busel, 2005; Bilodid, 1972).

In the scientific legal literature, the term is used frequently, in particular, within the concept of "legal principles". According to O.O. Punda, the latter are defined as a source, "legal basis", on which different types of different activities are constructed. Explicitly, this is initial fundamental provisions of activity in a particular sphere (Punda, 2001). According to other researchers, legal principles are the normative generalization of the highest level, the concentrated summary of the content of law (Pavlenko, 2009).

M.O. Margulis defines broadly enough the essence of legal principles, emphasizing that the latter characterize, above all, the complex influence of law on social relations, reflecting its effectiveness, that is, the maintenance of law and order. The legislation provides for legal principles at the level of normative prescriptions and doctrines, which establish and regulate the most important aspects of state and public organizations, fixes goals, defines legal possibilities and means, which ensure the gradual development of social relations. The legal principle is a dialectical unity of the reference and the result, inherent and obtained that exists in the implementation of legal influence (Margulis, 2006).

A. Strekhaliuk notes the philosophical content of the category "principles of law". He argues that in their philosophical and legal concepts, John Rawls, Friedrich Hayek, and Lon L. Fuller define the principles of law as a set of requirements to the legal system or as necessary conditions for the existence of the legal system and effective functioning of a "well-ordered society". That is, the principles of law have a clearly defined normative character. In Fuller's theory, the principles of law are the principles of the internal morality of law (Strekhaliuk, May 14-16, 2009).

Therefore, the legal principles are the legal basis of something, an ideological model, on which any legal category, phenomenon, institution, etc. are founded. However, this definition explains the essence of legal principles in their classical, general theoretical form. It should be emphasized that the latter are a meaningful basis of the category of administrative and legal principles of a certain type of activity, the specificities of which are under thorough consideration of many scientists.

For example, N.S. Panova emphasizes that the administrative and legal principles are a set of administrative and legal norms, which determine the main values, doctrines, tasks, forms, and methods of development of the normative and regulatory activity of specific state bodies, departments, structures, etc. (Panova, 2008). 
V.O. Kryvolapchuk and V.M. Klymenko define the administrative and legal principles as the means of determination (consolidation) of legal parameters (grounds, limits, methods) of a certain activity (Kryvolapchuk, Klymenko, 2014).

According to D.H. Zabroda, administrative and legal principles are a combination of parameters (characteristics) of the social phenomenon and legal relations, which require settlement using administrative and legal means. In addition, the scientist argues that in modern native textbooks and teaching manuals on the administrative law the terms "organizational and legal principles", "administrative and legal principles", "administrative and legal regulation", "administrative law" are used (Zabroda, 2013; Bytiak, Harashchuk, Diachenko, et al., 2007; Koval, 1998).

Therefore, the content of the category of administrative and legal principles of the tax authorities' activities can be outlined. Accordingly, in our opinion, they are initial provisions; a set of standards; a normatively defined and ensured by a circle of administrative norms model of the work of the tax authorities, according to which the latter are organized, as well as their functional orientation is defined.

Turning specifically to a comparative analysis of the administrative and legal principles of the activities of tax authorities in different countries, it is advisable to draw attention to national experience in this field. Nowadays, in Ukraine, fiscal functions are implemented by the State Fiscal Service (hereinafter - SFS).

According to the Regulation on the State Fiscal Service of Ukraine, the latter is a central executive body, which activities are directed and coordinated by the Cabinet of Ministers of Ukraine through the Minister of Finance and which implements the state tax policy, state policy on state customs, state policy on administering a single contribution to compulsory state social insurance, state policy on combating offenses in the application of tax, customs legislation, as well as legislation on payment of a single contribution (Pro derzhavnu fiskalnu sluzhbu Ukrainy, 2014). The main tasks of SFS are:

1) realization of the state tax policy and policy on state customs, the state policy on combating offenses during the application of tax, customs legislation; control, within the limits of authorities provided for by law, for revenues to the budgets and state target funds of taxes and fees; the state policy on monitoring the production and circulation of alcohol, alcoholic beverages, and tobacco products, the state policy on administering a single contribution, as well as the combating violations in the application of legislation on payment of a single contribution; the state policy on monitoring the timely execution of settlements in foreign currency within the statutory period; compliance with the order of cash settlements for goods (services), as well as control over licenses for economic activities subject to licensing in accordance with the law, commercial patents;

2) making proposals to the Minister of Finance for ensuring the formation of: the state tax policy;

the state policy on state customs;

the state policy on combating offenses during the application of tax, customs legislation, monitor receipts to budgets and state trust funds of taxes and duties, customs, and other payments;

- the state policy on monitoring the production and circulation of alcohol, alcoholic beverages, and tobacco products;

the state policy on administering a single contribution, as well as the combating violations in the application of legislation on payment of a single contribution;

- the state policy on monitoring the timely execution of settlements in foreign currency within the statutory period; compliance with the order of cash settlements for goods (services), as well as control over licenses for economic activities subject to licensing in accordance with the law, commercial patents (Pro derzhavnu fiskalnu sluzhbu Ukrainy, 2014).

Therefore, the tax authorities of Ukraine have a wide range of functions. According to them, to organize its activities SFS:

- provides, within the limits of the authorities provided bylaw, the implementation of measures for the prevention of corruption and control over their implementation in the apparatus of SPS and its territorial bodies;

- staffs the SFS apparatus and leadership positions in the territorial bodies, forms a personnel reserve for corresponding positions, organizes work on training, retraining, and advanced training of employees of the SFS apparatus, its territorial bodies;

- organizes scheduled financial work in the SFS apparatus and its territorial bodies, exercises monitoring of the use of financial and material resources, ensures the organization and improvement of accounting in accordance with the procedure established by law;

- provides the territorial authorities of SFS with methodological and practical assistance in organizing work, monitors such work;

- organizes information and analytical support for SFS and automatization of its activities (Pro derzhavnu fiskalnu sluzhbu Ukrainy, 2014).

It should be noted that SPS and its territorial bodies have units of the tax police. In accordance with Section XVIII-2 of the Tax Code of Ukraine, the tax policy is a system of special units for combating tax offenses acting within the respective supervisory bodies, and monitors the compliance with tax laws, performs operational and search, criminal and procedural, security functions (Pro derzhavnu fiskalnu sluzhbu Ukrainy, 2014; Podatkovyi kodeks Ukrainy, 2011). The key objectives of the tax police are:

- prevention of criminal and other offenses in taxation and budgeting, their disclosure, investigation, and proceedings in cases of administrative violations;

- search for persons who are hiding from the investigation and the court for criminal and other offenses in taxation and budgeting; 
- prevention and counteraction of corruption in regulatory bodies and disclosing its facts;

- ensuring the safety of officials of the regulatory bodies, protecting them against unlawful acts related to the performance of official duties (Podatkovyi kodeks Ukrainy, 2011).

It should be noted that the experience of the EU member countries in the organization of the tax system differs significantly from the national one. O.O. Bandurka argues that the experience of Ukraine on constructing the tax system in general is rather limited since, under administrative-command socialism, relations between the state and enterprises were based on the direct withdrawal of a significant part of their income to the budget in the form of deductions from profit and various payments. The experience of countries with a long history of the effective functioning of the tax system shows that the precondition for such establishment is the provision of bodies, specially authorized for combating tax offenses, with a sufficiently wide range of rights, as well as a clear definition of their responsibilities. In addition, the scientist argues that in the developed countries of the world, taxation and tax authorities are one of the pillars of their economic systems. They are quite complex, considering, on the one hand, the number of taxpayers and the number of types of taxes and fees, and on the other hand, the amount of legal regulation. Therefore, special state bodies are needed to implement the fiscal role of the state and ensure effective budget revenues (Bandurka, 2007).

The mentioned above proposition is confirmed by the example of the administrative and legal principles of the activities of the tax authorities of many countries of the European Union.

For example, in Italy, along with the State Police and the Carabinieri Corps, the General Command of the Financial Guard, forming a part of the Ministry of Finance, monitors receipts of mandatory payments to budgets, and accordingly the disclosure and investigation of economic crimes in taxation. T.V. Saraskina noted that this body was formed in 1881. It consists of the Central and Regional Commands. The Central Command is located in Rome, and three special units, the Central Unit of Tax Police, the Special Unit of the Currency Police, the Central Service for the Investigation of Organized Crime in the Economy, are subordinated to it (Saraskina, 2000).

The main functions of this department are control over the payment of taxes, prevention, disclosure, and investigation of financial crimes. It should be noted that the officials of the General Command of the Financial Guard have fiscal responsibilities of tax inspections and police rights in terms of control, in particular, operational measures and criminal investigations. They have the right of access to enterprises, firms, banks, and to any documents in order to verify the objects of taxation and tax control without obtaining a court order for such actions (Saraskina, 2000; Heha, 1997).
In Greece, the system of fiscal authorities is headed by the Ministry of Economy, which has two subordinated independent entities, the State Economic Service with the task of charging and collecting taxes and other mandatory payments, reviewing, controlling, and issuing documents of payers, and the Service for Combating Economic Crimes, which is equated to the state police with the task of checking compliance of taxpayers with the rules of fiscal legislation (Harust, 2005).

It is worth to consider the administrative and legal principles of the activities of the tax authorities of Germany because the experience of this state in filling the budget with the help of special, legally determined payments is quite progressive. This aspect is related to the specificities of this country development. In particular, O.P. Kyrylenko, T.O. Kizyma, N.Ya. Kravchuk, V.P.Horin, and others stated that historically and chronologically, Germany became one of the first countries in the world, where, under the influence of the workingclass movement and trade union organizations, social laws were introduced: sickness insurance, disability, retirement provision for workers, restrictions on the use of child labour. In 1891, Germany was the first to introduce a global income tax; in 1916, first introduced a tax on turnover, or a universal excise tax, on the basis of which, subsequently, VAT was introduced. In modern conditions, Germany is one of the most economically developed countries in the world (Kizyma, Kravchuk, Horyn et al., 2013).

The main tax authority in Germany is the Tax Service, which is a department of the Federal Ministry of Finance. The Federal Tax Office has a central unit, which is responsible for taxes. Besides the central apparatus, the German system also has a regional apparatus (the Länder). Each of the Länder (regions) has its own Ministry of Finance. Accordingly, today Germany has 16 territorial units, called the Länder, and 16 similar the Länder Ministries of Finance. Usually, a politician, not a specialist in taxation, is elected to the post of minister. The person who understands taxes and whose opinions are heeded is the senator or his first deputy. $\mathrm{He} / \mathrm{she}$ is an official. Typically, a high-level specialist is chosen for this position. A university professor, who has retired, or a high-ranking official of the tax service can be chosen. The senator is responsible for enforcing tax laws (Law and Institutions of the European Union, 1994). Moreover, some scholars state the presence of law enforcement functions in the activities of the tax service of Germany and its subordinate units. For example, in a separate state for the purpose of criminal and administrative prosecution of violators of tax legislation, special units, departments of criminal cases and penalties, are formed in the financial authorities (Teliatnikov, 1993). These bodies include well-trained investigative departments with a high level of material and technical support, such as eavesdropping and sound recording equipment, laboratories where it is possible to analyse the authenticity of documents 
submitted by taxpayers, handwriting, as well as carry out chemical and other forensic examinations. German tax authorities receive information on tax evasion from the police, prosecutors, security services, and citizens. According to an internal instruction, such informants are paid a reward of up to $10 \%$ of the amount accrued for nonpayment of tax penalties. During the tax control, German tax authorities have the right: to withdraw financial documents from banks, insurance companies; to apply confiscation of business documentation; to conduct investigations on advocates and consultants' charges of tax evasion (Arnim, Bartlshperger, Begge, et al., 1994).

For comparative analysis, the administrative and legal principles of the activities of tax authorities in France are remarkable. In its economic growth, this country is considered one of the most powerful, which is reflected in the specificities of the system of control and tax authorities. In the course of her scientific research, K.P. Proskura determines that the main body in taxation in France is the General Directorate of Taxes, which is a part of the Ministry of Economy, Finance and Industry. The specified body performs tax tasks (preparation of draft laws on taxation, determination of the total amount of tax revenues, an organization of tax control, conducting tax expertise, etc.) and certain civil legal tasks (control and accounting of civil and land legal relations, recording various inventories, etc.). The organizational structure of the tax body is based on the functional-territorial principle and has three levels: national, regional, and lower. The Office of National and International Controls carries out control over the activities of large enterprises, which is a part of the central office. Lower divisions inspect small businesses only. French tax authorities have the right to decide on the liquidation of an enterprise if, within three months, it or its actual location cannot be found (Proskura, 2012).S.O. Koretska notes that in the structure of the above-mentioned department, there are special structural units, such as the Central Tax Administration and the Central Administration of Customs and Other Revenues. The Central Tax Administration consists of five departments:

- Department of Preparation of Tax Legislation;

- Department of General Tax Administration, which provides for the accumulation of tax revenues in the state budget;

- Dispute Department, which deals with complaints and prepares legal materials engaged;

- Department of Land and State Property, which is responsible for cadastral valuation and lands, management of movable and immovable state property; - Personnel Department (Koretska, 2011).

Analysing the administrative and legal principles of the activity of tax authorities in the EU, the experience of the Kingdom of Sweden is worth considering. The tax system of this country is characterized by high taxation. Tax revenues in the Swedish budget make up more than $50 \%$ of GNP. Income tax and profits tax provide
$40 \%$ of all tax revenues, and social tax provides $25 \%$. In addition, Swedish law does not provide for tax breaks. However, such a tax system has provided Sweden with the smallest difference in the world between the highest and lowest levels of consumption. Other characteristic features of the Swedish taxation system are stability, flexibility, high-quality state regulation, anti-inflationary orientation (Stukalo, Lytvyn, Derkach, 2014).

A well-developed tax system in Sweden should require an efficient and extensive tax administration structure that would ensure respect for and compliance with tax laws by all without exception. However, the Kingdom of Sweden, along with countries such as Belgium, Denmark, Portugal, Finland and others, has a relatively compact structure of tax authorities (Nosikov, 2016).

The authority to collect taxes, verify their correctness, and collect tax arrears is charged to a special agency, the National Tax Office, though subordinated to the Ministry of Finance and the Government, but independent of the latter organization. The activity of the service is based on the principle that proper things must be done simply, while illegal must be difficult to implement. The organizational structure of the tax authorities is based on three models. Everyone must pay exactly as much as provided for by the parliament; the one, who has not paid fully, should pay total sum; and the one, who has overpaid, should get surplus of money back. The return of surplus of paid taxes operates immediately (in automatic mode); there is no delay (Yarenko, 2009; Lykova, 2013).

M.O. Vysotsky underlines one more important feature of the organization of tax authorities of the Kingdom of Sweden. The scientist indicates that some departments (inspections) are in charge of working with large taxpayers, others work with foreign enterprises. The departments (inspections) of indirect tax, which staff has specialists in foreign economic activity, carry out the calculation and payment of VAT. In addition, the National Tax Office is authorized to administer taxes and fees, keep records of taxpayers, verify tax declarations, serve tax advisory, observe and monitor compliance with tax laws, etc. (Vysotskii, 2002; Udiak, 2014).

It should be noted that the tax authorities of the Kingdom of Sweden operate with the high level of automation. Thus, for tax control, the declaration of taxpayers is in an electronic form entirely. At the same time, V.M. Melnyk accentuates the rather unusual (as for the East European countries) practice of "guardianship" in relation to the payer. Thus, local tax departments are obliged to send the declaration to the company a month before the deadline for its submission, reminding the payer of duties. Moreover, the timeliness of such "reminders" is monitored quite strictly (Melnyk, 2004).

The Financial Intelligence Service is in charge of the investigation of crimes and tax offenses in the Kingdom of Sweden. Structurally it is a part of the Chief Police Department. This is an extremely interesting experience 
in combating tax evasion because, despite some of the highest tax rates in Europe (which should have caused a significant level of crime), there is no separate tax police service in this sphere (Udiak, 2014).

In Spain, the administrative and legal principles of the tax authorities are under constant improvement since the 70 s of the twentieth century, after the tax reform. Therefore, in 1992 the organizational structure of the tax service was changed. In particular, out of the Ministry of Economy and Finance, the Tax Administration was allocated and then the Tax Agency was formed on its basis. It organized the tax service, tax authorities and planned their activities; monitored compliance with tax legislation; provided regional, provincial, and municipal tax administrations with material and technical support. The main tasks of the Tax Agency were:

- to reduce indirect taxes and indirect tax burden, establish the assistance system for taxpayers, and the develop information services for taxpayers and tax assistance by phone, create a database of questions and answers, shorten terms for answering questions and citizens' requests;

- to strengthen the regime of objective evaluation by modules. Mostly they were designed to work with small business entities to simplify the procedure for paying taxes and improve the efficiency of their collection;

- to inspect and control the performance of tax duties and combat crime (Stukalo, Lytvyn, Derkach, 2014).

In addition, N. Kiriienko notes that the staff of the newly formed Tax Agency is divided into inspectors and tax agents. Tax inspectors have extensive authorities, even the right to reduce penalties up to 50 points for co-operation in making decisions based on the results of inspections. A tax agent must have a secondary vocational education; he performs less-skilled work, such as verification of facts, selection of information and other (Kirienko, 1999).

In the activities of the tax authorities of Spain, as in many other European Union countries, information technologies are introduced and used actively. Thus, in their work, officials of tax authorities use information from the data bank on taxpayers. Such a data bank, formed in the Information Department, accumulates information on wage payments, on the activities of persons of free occupations, on real estate and transactions with it, on financial transactions with securities and currency funds, sale and purchase abroad, on founders of joint stock companies, including individuals, the results of inspections over the past 6 years (in Spain the statute of limitations is 5 years), as well as information from third parties about the debt. There are no privacy restrictions for collecting information by this department (Kniazeva, Chernika, (Eds), 1997).

\section{Conclusions}

Therefore, a comparative analysis of the administrative and legal principles of the activities of tax authorities of Ukraine and the EU member countries revealed that foreign experience in the sphere of control and coordination of the tax system has a wide range of positive moments. Some aspects of active models of constructing and operating tax offices in Europe are quite logical and effective; consequently, in our opinion, it would be expedient to use them in Ukraine. Therefore, it is necessary to adopt the experience of the EU countries with regard to:

- firstly, the scope of the administrative authorities of the controlling bodies and their officials, that is, a wide range of authorities in all issues related to the imposition of fines, inspections, etc.;

- secondly, the introduction, regulatory support, and active use of information technologies in the activities of tax authorities to improve the efficiency of the work of the latter.

However, based on the comparative analysis of the administrative and legal principles of the activities of tax authorities in the EU and Ukraine, it can be concluded that nowadays the national organizational model of the State Fiscal Service is more accomplished. The structural subordination of this department proves it. Contrasting such developed countries as Germany, France, Italy, etc., SFS in Ukraine is not a part of the structure of the Ministry of Finance, in accordance with legislation, that, in our opinion, ensures the objectivity and impartiality of the activities of the latter and its officials.

\section{References:}

Busel V.T. (2005). Velykyi tlumachnyi slovnyk suchasnoi ukrainskoi movy [Great explanatory dictionary of modern Ukrainian language]. K., Irpin: PTF Perun, 1728 p.

Bilodid I.K. (1972). Slovnyk ukrainskoi movy [Dictionary of the Ukrainian language]. I.K. Bilodid (Ed.). Kyiv: Naukova dumka, $744 \mathrm{p}$.

Punda O.O. (2001). Vykorystannia danykh, oderzhanykh v rezultati zastosuvannia naukovo-tekhnichnykh zasobiv, dlia dokazuvannia $\mathrm{v}$ kryminalnomu protsesi [Use of data obtained by application of scientific and technical means for evidence in a criminal proceeding] (Dissertation). Ivan Franko National University of Lviv, Lviv, 216 p.

Pavlenko M.V. (2009). Pryntsypy bankivskoho kontroliu - mizhnarodno-pravovi aspekty [Principles of banking control: International legal aspects]. Chasopys Kyivskoho universytetu prava [Journal of Kyiv University of Law], 1, 103-106.

Margulis M.A. (2006). Normotvorchestvo korporativnykh obiedinenii v oblasti sporta [Rulemaking for corporate associations in sports] (Dissertation). Moscow: RSL, 197 p. 
Strekhaliuk A. (May 14-16, 2009). Filosofskyi sens poniattia zasady prava u suchasnii filosofii prava (Liberalni kontseptsii) [Philosophical meaning of the concept "principles of law" in the modern philosophy of law (Liberal concepts) ]. Humanities \& Social Sciences 2009 (HSS - 2009), 306-307.

Panova N.S. (2008). Administratyvno-pravovi zasady rozvytku derzhavnoho upravlinnia $\mathrm{v}$ suchasnii Ukraini [Administrative and legal principles of development of state administration in modern Ukraine] (Dissertation Abstract). Kryvolapchuk V.O., Klymenko V.M. (2014). Analiz administratyvno-pravovykh zasad diialnosti derzhavnoi sluzhby okhorony pry MVS Ukrainy [Analysis of the administrative and legal principles of the activity of the state guard service at the Ministry of Internal Affairs of Ukraine]. Nauka i pravookhorona [Science and law enforcement], 1(23), 5-11.

Zabroda D.H. (2013). Administratyvno-pravovi zasady: sutnist ta zmist katehorii [Administrative and legal principles: The nature and content of the category]. Administratyvne pravo i protses [Administrative law and process], 2(4), 45-51.

Bytiak Yu.P., Harashchuk V.M., Diachenko O.V. et al. (2007). Administratyvne pravo Ukrainy: pidruchnyk [Administrative law of Ukraine: Textbook]. Yu.P. Bytiak, (Ed.). K.: YurinkomInter, 544 p.

Koval L.V. (1998). Administratyvne pravo [Administrative law]. K.: Venturi, 208 p.

Pro derzhavnu fiskalnu sluzhbu Ukrainy [On the State Fiscal Service of Ukraine] (Decree no. 236 of May 21, 2014). Ofitsiinyi visnyk Ukrainy [Official Bulletin of Ukraine], 55, 1507 p.

Podatkovyi kodeks Ukrainy [The Tax Code of Ukraine] (Law no. 2755-VI of December 02, 2010). Vidomosti Verkhovnoi Rady Ukrainy [Bulletin of the Verkhovna Rada of Ukraine]. (2011), 13, 112 p.

Bandurka O.O. (2007). Upravlinnia derzhavnoiu podatkovoiu sluzhboiu v Ukraini: orhanizatsiino-pravovi aspekty [Management of the State Tax Service in Ukraine: Organizational and legal aspects] (Dissertation). Kyivskyi mizhnarodnyi universytet, Kyiv, 500 p.

Saraskina T.V. (2000). Orhanizatsiino-pravovi zasady diialnosti podatkovoi militsii Ukrainy [Organizational and legal principles of the activity of the tax militia of Ukraine] (Dissertation). University of Internal Affairs of Ukraine, Kharkiv, 189 p.

Heha P.T. (1997). Pravovyi rezhym opodatkuvannia v Ukraini [Legal regime of taxation in Ukraine]. K.: YURINKOM, 143 p.

Harust, V.Yu. (2005).Zarubizhnyi dosvid zdiisnennia kontroliu za spravlianniam podatkiv ta inshykh oboviazkovykh platezhiv: Mozhlyvist yoho vykorystannia v Ukraini [Foreign experience in monitoring the collection of taxes and other mandatory payments: Possibility of implementing in Ukraine]. Pravo i bezpeka [Law and safety], 4(3), 57-60. Kizyma T.O., Kravchuk N.Ya., Horyn V.P. et al. (2013). Finansy zarubizhnykh krain: navchalnyi posibnyk [Finance of foreign countries: Textbook]. O.P. Kyrylenko (Ed.). Ternopil: Ekonomichna dumka, 287 p.

Law and Institutions of the European Union. London, Dublin, Edinburg, Butterworths. (1994), 336-340.

Teliatnikov N.B. (1993). Iz opyta raboty nalogovykh sluzhb Germanii [From the experience of the tax services of Germany]. Finansy [Finance], 10 p.

Arnim G.G., Bartlshperger R., Begge G. et al. (1994). Gosudarstvennoe pravo Germanii [State law of Germany] (Vols. 1-7), 2. M.: Institute of State and Law, RAS, 311 p.

Proskura K. (2012). Podatkove administruvannia u rozvynenykh yevropeyskykh krainakh [Tax administration in developed European countries]. Ekonomichnyi analiz [Economic analysis], 11(1), 203-206.

Koretska S.O. (2011). Analiz podatkovoi systemy Frantsii [Analysis of the tax system of France]. Ekonomika ta derzhava [Economy and the state], 12, 27-29.

Stukalo N.V., Lytvyn M.V., Derkach M.I. (2014). Hlobalni finansy: navchalnyi posibnyk [Global Finances: Textbook]. Dnipropetrovsk, 1092 p.

Nosikov D.M. (2016). Systema orhaniv, shcho zdiisniuiut fiskalnu funktsiiu derzhavy: teoretyko-pravovyi aspekt [The system of organs carrying out the fiscal function of the state: Theoretical and legal aspect]. Naukovyi visnyk Uzhhorodskoho natsionalnoho universytetu [Scientific Bulletin of Uzhgorod National University], 37-42.

Yarenko H. (2009). Struktura ta orhanizatsiia roboty podatkovykh orhaniv u zarubizhnykh krainakh [Structure and organization of the tax authorities in foreign countries]. Visnyk KNTEU [Journal of the KNTEU], 2, 114-126.

Lykova L.N. (2013). Nalogovye sistemy zarubezhnykh stran: uchebnik dlia magistrov [Tax systems of foreign countries: Textbook for masters]. M.: Urait, 428 p.

Vysotskii M.O. (2002). O shvedskom opyte nalogovogo administrirovaniia [About the Swedish experience of tax administration]. Nalogovyi vestnik [Taxation Bulletin], 1, 121-125.

Udiak V.I. (2014). Osoblyvosti kompetentsii fiskalnykh orhaniv zarubizhnykh krain pry realizatsii podatkovoi polityky [Features of the competence of fiscal authorities of foreign countries in the implementation of tax policy]. Naukovyi visnyk Mizhnarodnoho humanitarnoho universytetu [Scientific bulletin of the Tax Service of Ukraine], 9-2(1), 142-144.

Melnyk V. (2004). Dosvid administruvannia podatkiv u zarubizhnykh krainakh [Experience of tax administration in foreign countries]. Visnyk podatkovoi sluzhby Ukrainy [Bulletin of the Tax Service of Ukraine], 38-39. Retrieved from: https://www.zakon-i-normativ.info/index.php/component/ lica/ ?href=0\&view=text\&base=1\&id=221209\&menu=331807

Kirienko N. (1999). Nalogovaia sistema Ispanii [Tax System of Spain]. Vestnik nalogovoi sluzhby Ukrainy [Bulletin of the Tax Service of Ukraine], 47 p.

Kniazeva V.G., Chernika D.G. (Eds) (1997). Nalogovyie sistemy zarubezhnykh stran: Uchebnik dlia vuzov [Tax systems of foreign countries: Textbook for higher educational institutions]. M.: Zakon i pravo, YUNITI, 191 p. 